\title{
Acute exposure to hair bleach causes airway hyperresponsiveness in a rabbit model
}

\author{
T. Mensing, W. Marek, M. Raulf-Heimsoth, X. Baur
}

\begin{abstract}
Acute exposure to hair bleach causes airway hyperresponsiveness in a rabbit model. $T$. Mensing, W. Marek, M. Raulf-Heimsoth, X. Baur. (OERS Journals Ltd 1998.

ABSTRACT: Ammonium persulphate (APS) and hydrogen peroxide $\left(\mathrm{H}_{2} \mathrm{O}_{2}\right)$ are used as oxidants in many industrial processes and are the main constituents of standard hair bleaching products. In a previous study, it was demonstrated that aerosols of APS induce alterations in airway responsiveness.

The present study examined whether exposure for $4 \mathrm{~h}$ to a hair bleach composition (containing APS, potassium persulphate and $\mathrm{H}_{2} \mathrm{O}_{2}$ ) or $\mathrm{H}_{2} \mathrm{O}_{2}$ could induce airway hyperresponsiveness and/or an obstructive ventilation pattern in a rabbit model.

Exposure to the aerosols altered neither baseline airway resistance, dynamic elastance, slope of inspiratory pressure generation nor arterial blood pressure and blood gas measurements. Similarly to APS, hair bleach aerosols containing $\breve{S} 10.9 \mathrm{mg}^{-3} \mathrm{~m}^{-3}$ persulphate (ammonium and potassium salt) in air and $\check{S} 1.36 \mathrm{mg} \cdot \mathrm{m}^{-3} \mathrm{H}_{2} \mathrm{O}_{2}$ in air caused airway hyperresponsiveness to acetylcholine after $4 \mathrm{~h}$ of exposure. Aerosolized $\mathrm{H}_{2} \mathrm{O}_{2}\left(\breve{\mathbf{S}} 37 \mathrm{mg} \cdot \mathrm{m}^{-3}\right.$ in air) did not influence airway responsiveness to acetylcholine.

The results demonstrate that hair bleaching products containing persulphates dissolved in $\mathrm{H}_{2} \mathrm{O}_{2}$ cause airway hyperresponsiveness to acetylcholine in rabbits. Eur Respir J 1998; 12: 1371-1374.
\end{abstract}

Professional Associations' Research Institute for Occupational Medicine, Institute at the Ruhr University, Bochum, Germany.

Correspondence: T. Mensing

Berufsgenossenschaftliches Forschungsinstitut für Arbeitsmedizin (BGFA)

Bürkle-de-la-Camp-Platz 1

D-44789 Bochum

Germany

Fax: 49234316269

Keywords: Airway hyperresponsiveness ammonium persulphate hair bleach

hydrogen peroxide rabbits

Received: June 171996

Accepted after revision July 151998
In addition to skin diseases, respiratory disorders have been frequently reported among hairdressers and chemical workers exposed to persulphates [1-7]. These substances are inhaled as aerosols or as vapours during the mixing of bleaching powder or paste with the bleaching solution, which contains hydrogen peroxide $\left(\mathrm{H}_{2} \mathrm{O}_{2}\right)$, and during application to the hair $[8,9]$. In industrial settings, persulphates are used in bleaching processes, for etching of metal surfaces or as polymerization catalysts. $\mathrm{H}_{2} \mathrm{O}_{2}$ is also used for many bleaching processes and in chemical production processes [10].

A previous study [11] examined the influence of the crude hair bleach component ammonium persulphate (APS) on the development of airway hyperresponsiveness (AHR) in a rabbit model. Exposure was performed twice for $2 \mathrm{~h}$ to $500 \mathrm{mg} \cdot \mathrm{m}^{-3}$ APS in air. After the first $2 \mathrm{~h}$ of exposure to $500 \mathrm{mg} \cdot \mathrm{m}^{-3}$ APS, bronchoconstriction induced by acetylcholine (ACh) increased significantly. After another $2 \mathrm{~h}$ of exposure, the response to ACh was further increased. After $4 \mathrm{~h}$ of exposure to nebulized $50 \mathrm{mg} \cdot \mathrm{m}^{-3}$ APS in air, airway responsiveness (AR) was significantly enhanced in a similar manner. No increase in AR to ACh was found during exposure to a concentration of $5 \mathrm{mg} \cdot \mathrm{m}^{-3}$ APS in air. During the APS challenge, baseline respiratory and cardiovascular parameters remained unaltered in all groups.

The aim of the present examination was to investigate, in a rabbit model, the influence of a commercial hair bleach with a standard composition and that of $\mathrm{H}_{2} \mathrm{O}_{2}$ alone on the development of AHR at concentrations near and above the threshold limit volume (TLV).

\begin{abstract}
Methods
\section{Experimental set-up}

A detailed description of the rabbit model and the statistical data analysis has been presented in previous papers $[12,13]$. Male and female white New Zealand rabbits of the same breed and of similar age and body weight (3.5-4.0 $\mathrm{kg}$ ) were anaesthetized with $20-30 \mathrm{mg} \cdot \mathrm{kg}^{-1}$ thiopentobarbital sodium (Trapanal®; Byk Gulden, Konstanz, Germany) after premedication with $25 \mathrm{mg} \cdot \mathrm{kg}^{-1}$ ketamine hydrochloride (Ketanest ${ }^{\circledR}$; Parke-Davis, Berlin, Germany) and $5 \mathrm{mg}$. $\mathrm{kg}^{-1}$ xylazin (Rompun ${ }^{\circledR}$; Bayer, Leverkusen, Germany) and placed in a supine position. The level of anaesthesia was kept constant by continuous infusion of $0.2 \mathrm{mg} \cdot \mathrm{kg}^{-1} \cdot \mathrm{h}^{-1}$ thiopentobarbital sodium via a catheter, inserted into the femoral vein. The body temperature was maintained at $39 \pm 0.5^{\circ} \mathrm{C}$ by means of a thermocontroller, connected to a heating pad. The animals were intubated (3.0 mm i.d.; Mallinckrodt, Athlone, Ireland) and breathed room air spontaneously. All animals were in a healthy condition, free from signs of acute airway infections and had not previously suffered from any known infections.
\end{abstract}

\section{Recording of respiratory and cardiovascular parameters}

Respiratory air-flow $\left(V^{\prime}\right)$ was recorded by a Fleisch's head (00; Hugo Sachs, March, Germany) attached to the animal's mouth. Tidal volume $(V \mathrm{~T})$ was obtained by integration of the inspiratory flow signal. Differences in oesophageal pressure (ýPoes) were measured using a catheter 
inserted in the oesophagus connected to a pressure transducer. Dynamic elastance ( $E$ dyn) was calculated from ýPoes/ $V \mathrm{~T}$. By catheterization of the femoral artery, cardiovascular parameters were measured and small blood samples (about $0.4 \mathrm{~mL}$ ) were collected to examine blood gases and correlated acid-base parameters. Data were recorded on a polygraph (Graphtec Linearcorder WR 3310; Graphtec, Tokyo, Japan) and, after analogue/digital conversion of the measured signals, digitized on a personal computer.

\section{Airway hyperresponsiveness in in vivo experiments}

Changes in airway response to aerosols of $0.2 \%$ and $2 \%$ ACh solutions in saline, generated by a commercial nebulizer (Pari, Clinic II; Starnberg, Germany), were investigated. Solutions $(0.13 \mathrm{~mL})$ were nebulized in $5.7 \mathrm{~L}$ room air. $\mathrm{min}^{-1}$ and stored in a reservoir bag. The particles had a diameter of $0.5-5.5 \mu \mathrm{m}$. During the challenge tests, animals inhaled for $1 \mathrm{~min}$ with a mean of $1.1 \pm 0.3 \mathrm{~L}$ from the ACh aerosol [12], which corresponded to a total dose of 0.05 and $0.5 \mathrm{mg} \mathrm{ACh}$, respectively $(0.2 \%$ and $2.0 \%$ solution).

Changes in airway responses were measured when respiratory and cardiovascular parameters were constant. At the beginning, inhalation of aerosolized $0.2 \%$ ACh solution did not change baseline values of $E$ dyn in healthy rabbits. Application of nebulized 2.0\% ACh solution caused a rise in $E$ dyn of $50-150 \%$ of the baseline value. Attention was focused on the responses to aerolized $2.0 \%$ ACh solution, before and after exposure to irritating agents. The responses to $\mathrm{ACh}$ were transient, lasting for $<15 \mathrm{~min}$.

Each group, consisting of eight or nine rabbits, inhaled one concentration of hair bleach or $\mathrm{H}_{2} \mathrm{O}_{2}$, respectively. All agents were tested at three different concentrations. ACh challenge tests were performed before and after 2 and $4 \mathrm{~h}$ of exposure. The chemicals $\left(\mathrm{NH}_{4}\right)_{2} \mathrm{~S}_{2} \mathrm{O}_{8}, \mathrm{~K}_{2} \mathrm{~S}_{2} \mathrm{O}_{8}$, and $\mathrm{H}_{2} \mathrm{O}_{2}$ (30\%) were obtained from Merck (Darmstadt, Germany).

Control group A. In control group A, animals $(n=9)$ were exposed twice for $2 \mathrm{~h}$ to aerosolized saline. The AR to ACh was tested before and after 2 and $4 \mathrm{~h}$ of exposure.

Exposure to hydrogen peroxide (groups $B-D$ ). Hydrogen peroxide was diluted in saline. The groups $(n=8$ each) were exposed to concentrations of 37 (group B), 7.5 (group C) or $0.75 \mathrm{mg} \cdot \mathrm{m}^{-3}$ (group D) $\mathrm{H}_{2} \mathrm{O}_{2}$ in air for $4 \mathrm{~h}$. The estimated (from concentration and minute volume) inhaled doses were $7.1,1.4$ and $0.1 \mathrm{mg}$, respectively.

Exposure to hair bleach solution (groups $E-G$ ). Three groups of animals ( $\mathrm{n}=8$ each) were exposed to three different concentrations of a nebulized hair bleach (dilutions of a commercial stock solution with standard composition). When nebulized, the total aerosol concentrations were 1,200, 120 or $12 \mathrm{mg} \cdot \mathrm{m}^{-3}$ in air (groups E-G), corresponding to the inhalation of 230,23 or $2.3 \mathrm{mg}$ hair bleach in $4 \mathrm{~h}$, respectively (for composition see table 1). The standard hair bleach was dissolved in saline and contained only bleaching agents (i.e. APS, potassium persulphate (KPS) and $\mathrm{H}_{2} \mathrm{O}_{2}$ ) without compounds for stabilization or perfume.
Table 1. - Concentrations $\left(\mathrm{mg} \cdot \mathrm{m}^{-3}\right.$ in air) of the individual compounds in the inhaled aerosols

\begin{tabular}{ccccccc}
\hline & \multicolumn{3}{c}{ Hair bleach composition } & & \multicolumn{2}{c}{ Crude substances } \\
\cline { 2 - 4 } \cline { 6 - 7 } & $\mathrm{H}_{2} \mathrm{O}_{2}$ & APS & KPS & & $\mathrm{H}_{2} \mathrm{O}_{2}$ & APS [11] \\
\hline Dilution $1: 10$ & 136 & 410 & 678 & & 37 & 500 \\
$1: 100$ & 13.6 & 41 & 67.8 & & 7.5 & 50 \\
$1: 1000$ & 1.36 & 4.1 & 6.78 & & 0.75 & 5.0 \\
TLV [14] & & & & 1.4 & 5 \\
TLV [15] & & & & & 5
\end{tabular}

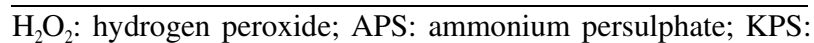
potassium persulphate; TLV: threshold limit value.

Statistical analysis. The data represent the mean \pm SD of $n=8$ or $n=9$ of the respective group. The significance of the differences between the ACh response before and after exposure to the chemical compounds was tested by Students' paired t-test [14]. Differences were considered significant for $\mathrm{p}<0.05$.

The experiments were performed with the written consent of the ethical commission for animal experiments.

\section{Results}

\section{Control group A}

Group A was exposed twice for $2 \mathrm{~h}$ to saline aerosols. The first inhalation of nebulized $2.0 \%$ ACh solution at the beginning increased $E$ dyn by about $100 \%$ of the baseline value from $2.5 \pm 0.3$ to $5.1 \pm 1.1 \mathrm{kPa} \cdot \mathrm{dL}^{-1}$. No significant response was found to aerosolized $0.2 \%$ ACh solution. Two 2-h exposure periods to saline aerosols did not influence the ACh responses (fig. 1).

\section{Influence of hair bleach on the development of airway hyperresponsiveness}

During exposure, the baseline respiratory and cardiovascular parameters remained unaltered. Exposure to an aerosol containing $1,200 \mathrm{mg} \cdot \mathrm{m}^{-3}$ of a hair bleach solution in air (group E) caused a significant increase in the response to $2.0 \%$ ACh after 2 and $4 \mathrm{~h}$ of exposure $(\mathrm{p}<0.05$ and $\mathrm{p}<$ 0.005 , respectively). In the groups exposed to $12 \mathrm{mg} \cdot \mathrm{m}^{-3}$ (group H) or $120 \mathrm{mg} \cdot \mathrm{m}^{-3}$ (group G), AR to ACh increased significantly after $4 \mathrm{~h}(\mathrm{p}<0.05)$ (fig. 2$)$.

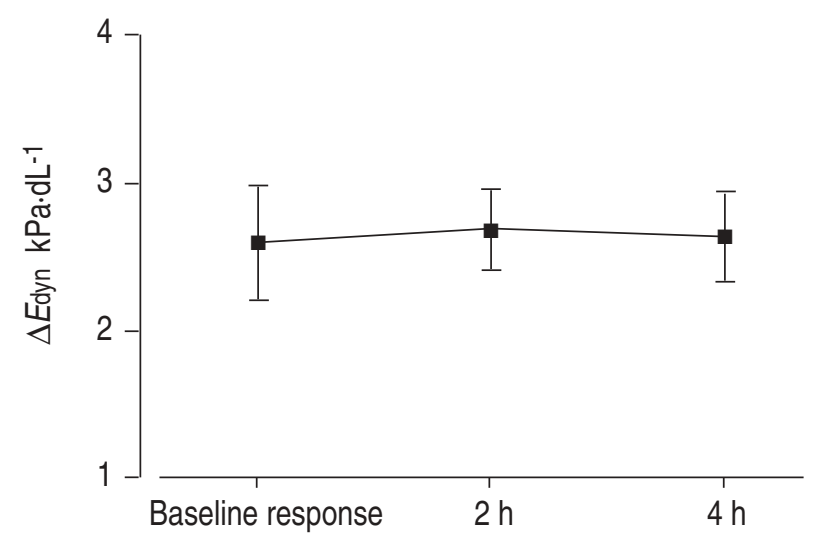

Fig. 1. - Changes in dynamic elastane (ýEdyn) after challenge with $2.0 \%$ acetylcholine hydrochloride before and $2 \mathrm{~h}$ and $4 \mathrm{~h}$ after exposure to saline $(\mathrm{n}=9)$. 


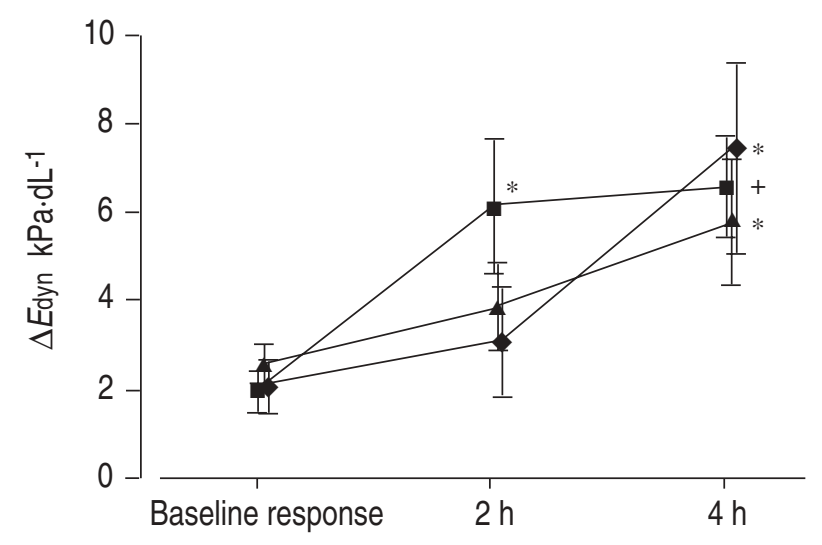

Fig. 2. - Changes in dynamic elastance (ýEdyn) after challenge with $2.0 \%$ acetylcholine hydrochloride before and $2 \mathrm{~h}$ and $4 \mathrm{~h}$ after exposure to three different concentrations of a hair bleach aerosol $\left(\diamond: 12 \mathrm{mg} \cdot \mathrm{m}^{-3}\right.$; $\left.\mathbf{\Delta}: 120 \mathrm{mg} \cdot \mathrm{m}^{-3} ; \mathbf{\square}: 1,200 \mathrm{mg} \cdot \mathrm{m}^{-3}\right)(\mathrm{n}=8){ }^{*}: \mathrm{p}<0.05,+\mathrm{p}<0.005$.

\section{Influence of hydrogen peroxide on the development of air-} way hyperresponsiveness

Baseline values of respiratory mechanical parameters were not significantly altered during and after $\mathrm{H}_{2} \mathrm{O}_{2}$ aerosol inhalation. The responses of Edyn after ACh challenge were not significantly altered after exposure to the three different $\mathrm{H}_{2} \mathrm{O}_{2}$ concentrations (groups $\mathrm{C}-\mathrm{E}$; fig. 3). However, after exposure to $37 \mathrm{mg} \cdot \mathrm{m}^{-3} \mathrm{H}_{2} \mathrm{O}_{2}$ in air, there was a small but nonsignificant trend towards an increased contractile response to $2 \% \mathrm{ACh}$.

\section{Discussion}

This study examined the influence of a standard hair bleach composition and the main constituents of hair bleach on the development of AHR in rabbits in vivo. APS [11] as well as the standard hair bleach $\left(12 \mathrm{mg} \cdot \mathrm{m}^{-3}\right)$, but not $\mathrm{H}_{2} \mathrm{O}_{2}\left(37 \mathrm{mg} \cdot \mathrm{m}^{-3}\right)$, caused significant increases in airway contractile responses to $\mathrm{ACh}$.

In the control group, exposed to saline aerosols, AR remained stable. In previous experiments, it was demonstrated that APS at concentrations $\breve{S} 50 \mathrm{mg} \cdot \mathrm{m}^{-3}$ in air caused AHR, after an exposure of only $4 \mathrm{~h} \mathrm{[11].} \mathrm{However,}$ exposure to hair bleach containing $11 \mathrm{mg} \cdot \mathrm{m}^{-3}$ persulphate

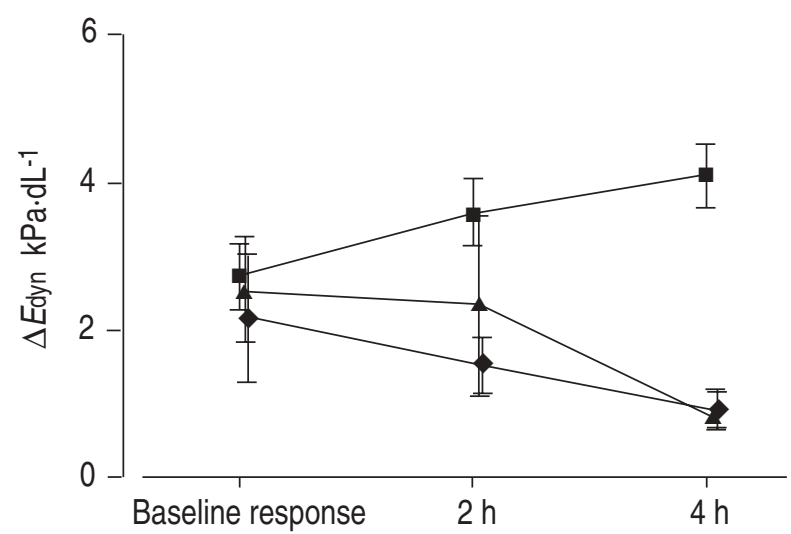

Fig. 3. - Changes in dynamic elastane (ýEdyn) after challenge with $2.0 \%$ acetylcholine hydrochloride before and $2 \mathrm{~h}$ and $4 \mathrm{~h}$ after exposure to $0.75(\diamond), 7.5(\Delta)$ and $37 \mathrm{mg} \cdot \mathrm{m}^{-3}(\boldsymbol{\square}) \mathrm{H}_{2} \mathrm{O}_{2}(\mathrm{n}=8)$
( $4 \mathrm{mg} \cdot \mathrm{m}^{-3}$ APS) also caused AHR after $4 \mathrm{~h}$ of exposure. Moreover, $5 \mathrm{mg} \cdot \mathrm{m}^{-3}$ pure APS resulted in an increase in eosinophil-released mediators in bronchoalveolar lavage (BAL) fluid in rabbits $[11,15]$. It seems likely that chronic exposure to APS at a concentration near the TLV $(5 \mathrm{mg}$. $\left.\mathrm{m}^{-3}\right)$, which may occur in some working environments (e.g. hairdressing salons, APS production), might cause airway inflammation. MERGET et al. [7] measured APS concentrations of $3.6 \mathrm{mg} \cdot \mathrm{m}^{-3}$ in a chemical production plant of persulphates.

The present results are partially in accordance with the experiments of LAST et al. [16]. These authors demonstrated that exposure to an APS concentration of $4 \mathrm{mg} \cdot \mathrm{m}^{-3}$ for 7 days, $23.5 \mathrm{~h} \cdot$ day $^{-1}$, caused a decreased body weight and an increased fresh lung weight. The discrepancy with the present results at $5 \mathrm{mg} \cdot \mathrm{m}^{-3}$ might be due to the longer exposure effects not evaluated in these experiments.

The persulphate concentrations in the hair bleach mixture and in the pure APS aerosol were different, so it is difficult to compare the two groups. However, no statistical difference can be obtained between the groups exposed to pure persulphate or hair bleach.

In the animals exposed to different concentrations of the strong oxidant $\mathrm{H}_{2} \mathrm{O}_{2}$, no enhanced responses to $\mathrm{ACh}$ were found. The reason for this outcome has not yet been clarified. The presence of glycoproteins or enzymes such as catalase or glutathione peroxidase, which metabolize $\mathrm{H}_{2} \mathrm{O}_{2}$ in the lung, may prevent the damage of airway epithelium function [17, 18] and hence the development of AHR. Although there was a trend towards an increased responsiveness to $2 \% \mathrm{ACh}$ after exposure to $37 \mathrm{mg} \cdot \mathrm{m}^{-3}, \mathrm{H}_{2} \mathrm{O}_{2}$ had no effects on $\mathrm{AR}$ in the concentrations used in hair bleach solutions. An effect of $\mathrm{H}_{2} \mathrm{O}_{2}$ at higher concentrations cannot be excluded. Moreover, the choice of the species and the model may influence the effect of $\mathrm{H}_{2} \mathrm{O}_{2}$ [19-21].

The hair bleach solutions contained neither perfumes nor stabilizing agents, the presence of which may vary in different commercial products, to avoid any influence of these compounds. Because of the very high concentration of persulphates in the hair bleach mixture, diluted solutions containing concentrations of the crude substances near the TLV were used.

The basic mechanisms of APS and hair bleach-induced AHR are still unclear and need further investigation. However, several mechanisms of action could explain the effect of persulphates on AR.

Although persulphates are stable in aqueous solutions, a small proportion decays to oxygen radicals [22]. A reaction with organic materials is mediated by the radicals - $\mathrm{SO}_{4}$ - or $\mathrm{OH}$. Inhaled oxidants damage epithelial cells $[23,24]$, and this may result in a loss of prostanoid inhibitory factors [25]. Oxidation of unsaturated fatty acids would result in an increased concentration of prostaglandins $\left(\mathrm{PGE}_{2}\right)$, which could also influence airway smooth muscle tone $[23,25]$.

Induced epithelium damage would favour airway contractile mechanisms. This is supported by the results of MunAKATA et al. [26], who showed that AR increased in the absence of an intact epithelium. Another explanation for the development of AHR may be the release of histamine from mast cells, as demonstrated by PARSONS et al. [27].

Further investigations into the cell and mediator profile in the BAL fluid demonstrated the participation of inflammatory cells and their mediators in the development of 
AHR after exposure to the examined substances in the lowest concentrations [15]. It is well known that eosinophils and their mediators, such as eosinophilic peroxidase, major basic protein and leukotrienes $\mathrm{C}_{4}, \mathrm{D}_{4}$ or $\mathrm{E}_{4}$, contribute to the development of AHR. A release of reactive oxygen species from inflammatory cells might cause damage to the epithelial cells [28]. KolLeR et al. [29] showed that APS may increase the generation of leukotrienes from human neutrophil granulocytes.

In summary, exposure to hair bleach containing about $10 \mathrm{mg} \cdot \mathrm{m}^{-3}$ persulphates increased airway hyperresponsiveness after $4 \mathrm{~h}$. Hydrogen peroxide in a 26 -fold concentration of the German threshold limit value neither altered respiratory parameters nor influenced airway hyperresponsiveness to acetylcholine. These results confirm the initiating toxic character of persulphates and hair bleach in concentrations near and above the threshold limit value of ammonium persulphate.

\section{References}

1. Blainey AD, Ollier S, Cundell D, Smith RE, Davies RJ. Occupational asthma in a hairdressing salon. Thorax 1986; 41: 42-50.

2. Fisher AA. Persulfate hair bleach reactions. Arch Dermatol 1976; 112: 1407-1409.

3. Schwaiblmair M, Baur X, Fruhmann G. Asthma bronchiale durch Blondiermittel im Friseurberuf. Dtsch Med Wschr 1990; 115: 695-697.

4. Baur X, Fruhmann G, Liebe Vv. Persulfat-Asthma und Persulfat-Dermatitis bei zwei Industriearbeitern. Respiration 1979; 38: 144-150.

5. Meindl K, Meyer R. Asthma und Urtikaria im FriseurBeruf durch persulfathaltige Blondiermittel. Zbl Arbeitsmed 1969; 3: 75-79.

6. Kleinhans D, Ranneberg KM. Sofortreaktionen durch Ammoniumpersulfat in Blondierpulvern. Allergologie 1989; 12: 353-354.

7. Merget R, Buenemann A, Kulzer R, et al. A cross sectional study of chemical industry workers with occupational exposure to persulphates. Occup Environ Med 1996; 53: 422-426.

8. Haarbleichmittel. In: Schrader K. Grundlagen und Rezepturen der Kosmetika, 2nd Edn. Heidelberg, Hürthig Buch Verlag, 1989; pp. 815-823.

9. Elvers B, ed. Ullmann's Encyclopedia of Industrial Chemistry, Vol. A12. Weinheim, VCH, 1989; p. 583.

10. O.A. Neumüler, ed. Römpps Chemie Lexikon, 7th Edn. Stuttgart, Franckh, 1977.

11. Mensing T, Marek W, Raulf-Heimsoth M, Baur X. Blondiermittelbestandteile als Auslöser einer bronchialen Überempfindlichkeit - Untersuchungen an einem Modell für berufsbedingte Lungenschädigungen. Pneumologie 1995; 49: 418-427.

12. Marek W, Potthast JJW, Marczynski B, Baur X. Role of substance $\mathrm{P}$ and neurokinin $\mathrm{A}$ in toluene diisocyanate- induced increased airway responsiveness in rabbits. Lung 1996; 174: 83-97.

13. Marek W, Potthast J, Marczynski B, Baur X. Toluene diisocyanates induction of airway hyperresponsiveness at the threshold limit value (10 ppb) in rabbits. Lung 1995; 173: 333-346.

14. Sachs L. Angewandte Statistik. Berlin, Springer, 1974.

15. Raulf-Heimsoth M, Mensing T, Marek W, Baur X. Zelluläre Zusammensetzung und Mediatorenprofil der bronchoalveolären Lavage des Kaninchens nach Exposition gegenüber Oxidationsmittel des Friseurhandwerks. Pneumologie 1996; 50: 125 (abstract).

16. Last I, Dasgupta PK, De Cesare K, Turkington BK. Inhalation toxicology of ammonium persulfate, an oxidant aerosol, in rats. Appl Pharmacol 1982; 63: 257-263.

17. Salathe M, Gulidmann P, Conner GE, Wanner A. Hydrogen peroxide scavenging properties of sheep airway mucus. Am J Respir Crit Care Med 1995; 151: 1543-1550.

18. Martin D, Korthuis RJ, Perry M, Townsley MI, Taylor AE. Oxygen mediated lung damage associated with radical $\alpha$ naphthylthiourea. Acta Physiol Scand 1986; S548: 119125.

19. Rhoden KJ, Barnes PJ. Effect of hydrogen peroxide on guinea-pig tracheal smooth muscle in vitro: role of cyclooxygenase and airway epithelium. Br J Pharmacol 1989; 98: 325-330.

20. Gupta JB, Prasad K. Mechanisms of $\mathrm{H}_{2} \mathrm{O}_{2}$-induced modulation of airway smooth muscle. Am J Physiol 1992; 263: L714-L722.

21. Szarek JL, Schmidt NL. Hydrogen-peroxide-induced potentiation of contractile responses in isolated rat airways. Am J Physiol 1990; 258: L232-L237.

22. Hollemann AF, Wiberg E. Lehrbuch der Anorganischen Chemie. Berlin, Walter de Gruyter, 1985.

23. Menzel DB. Oxidants and human health. J Occup Med 1976; 18: 342-345.

24. Bast A, Haenen GRMM, Doelman CJA. Oxidants and antioxidants: state of the art. Am J Med 1991; 91: 2S$13 \mathrm{~S}$.

25. Raeburn D, Webber SE. Proinflammatory potential of the airway epithelium in bronchial asthma. Eur Respir J 1994; 7: 2226-2234.

26. Munakata M, Huang I, Mitzner W, Menkes H. Protective role of epithelium in the guinea pig airway. J Appl Physiol 1988; 66: 1547-1552.

27. Parsons JF, Goodwin BF, Safford RJ. Studies on the action of histamine release by persulphates. Fd Cosmet Toxicol 1979; 17: 129-135.

28. Kroegel C, Kortsik C, Luttmann W, Werner P, Matthys H, Virchow JC Jr. Prinzipien der therapeutischen Intervention im Rahmen der allergischen Entzündungsreaktion. Allergologie 1994; 4: 134-142.

29. Koller M, Hilger RA, König W. Dual effect of ammonium persulfate on the generation of leukotrienes from human neutrophil granulocytes. Int Arch Allergy Immunol 1996; 110: 318-324. 